\title{
Human herpes virus 6 or Epstein-Barr virus were not detected in Guthrie cards from children who later developed leukaemia
}

\author{
G Bogdanovic', ÅG Jernberg ${ }^{2}$, P Priftakis ${ }^{3}$, L Grillner' and B Gustafsson ${ }^{*, 2}$ \\ 'Department of Clinical Microbiology, Karolinska University Hospital Solna, Karolinska Institutet, S-17I 76 Stockholm, Sweden; '²Department of \\ Paediatrics, Karolinska University Hospital, Huddinge, Karolinska Institutet, S-141 86 Stockholm, Sweden; ${ }^{3}$ Department of Oncology-Pathology, Cancer \\ Centre, Karolinska University Hospital Solna, Karolinska Institutet, S-I 7 I 76 Stockholm, Sweden
}

To investigate if children who later developed acute lymphoblastic leukaemia (ALL) were prenatally infected with human herpes virus 6 (HHV-6) and/or Epstein-Barr virus (EBV), Guthrie cards taken at birth were analysed by PCR. Guthrie cards from 54 patients with ALL and 47 healthy controls matched for age and birth place were tested negative for both HHV-6 and EBV DNA. All samples contained amplifiable DNA when tested by HLA-DQ PCR. Our negative findings suggest that childhood ALL is unlikely to be associated with an in utero infection with EBV or HHV-6.

British Journal of Cancer (2004) 9 I, 913-915. doi:I0.1038/sj.bjc.6602099 www.bjcancer.com

(c) 2004 Cancer Research UK

Keywords: childhood ALL; herpes virus; Guthrie cards; PCR; prenatal origin

Acute lymphoblastic leukaemia (ALL) is the most frequent childhood malignancy in Western countries. The different subtypes of leukaemia differ in their patterns of genetic change, natural history, prognosis and possibly aetiology (Doll, 1989; Ross, 1999). One model for the aetiology of childhood ALL is prenatal infection and such a maternal infection could affect foetal haematopoiesis early in the liver and later in the bone marrow (Ohls and Christensen, 2000).The relevant agent would have to cross the placenta, induce genomic instability in the lymphocytes and infect the foetus without causing severe foetal abnormalities (Smith, 1997). We have analysed human polyomaviruses (JCV and BKV) and human parvovirus B19 in Guthrie cards from children who later developed ALL, but could detect neither polyomavirus DNA nor parvovirus DNA from ALL cases or controls (Priftakis et al, 2003; Isa et al, 2004).

Epstein-Barr virus (EBV) and human herpes virus 6 (HHV-6) are two potentially oncogenic viruses widely distributed in the human population, which can be spread by vertical or horizontal (in utero) transmission. Since they persist and establish latency in their natural host after primary infection, they may be reactivated during immunosuppression (Matsuda et al, 1999). The viral latency is primarily established in lymphocytes, which may be important in relation to childhood ALL (Gustafsson et al, 2000; Salonen et al, 2002).

Our study was conducted to determine if a group of children with ALL were prenatally infected with HHV-6 or EBV. Guthrie cards taken at birth were collected and analysed for the presence of these viruses.

\footnotetext{
*Correspondence: Dr B Gustafsson; E-mail: britt.gustafsson@klinvet.ki.se
} Received 24 March 2004; revised 19 May 2004; accepted 30 June 2004

\section{PATIENTS AND METHODS}

\section{Patients}

We collected Guthrie cards from 54 children who had developed ALL. A total of 50 of these children had been diagnosed as pre-B ALL (either CD10 +, CD20 +, FAB L1 or L2) and four children were diagnosed as T-ALLs (CD3 + or CD8 +). In all, 24 children were diagnosed before the age of 4,16 children were between 5 and 9 years, 12 children were between 10 and 14 years of age and two children were older than 14 years. The median age at diagnosis was 5 years (range 9 months -17 years, mean 5.9 years). These children had been admitted for treatment at four different Paediatric Oncology Swedish Centres from 1980 through 2001. As a control group, we obtained 47 healthy controls that were matched for age and birthplace, and data from the controls were collected from the Swedish Medical Birth Register, which is a standardised set of medical records introduced in Sweden in 1973 (Cnattingius et al, 1990). The capillary blood from both groups was collected at 3-5 days of age. After the screening analysis, the Guthrie cards are stored at $4{ }^{\circ} \mathrm{C}$ at the PKU laboratory, at Karolinska University Hospital, Huddinge.

Two bone marrow-transplanted patients were positive for HHV6 and EBV DNA, respectively. These two patients were included as positive controls. Guthrie cards 'spiked' with blood from these patients were tested for the presence of HHV-6 or EBV DNA. Blood samples were taken from these two patients and added to a new Guthrie card.

\section{Methods}

DNA extraction by minimal essential medium (MEM) At the time of analysis, the filter paper samples were stored at room temperature before extraction. The extraction method utilised was MEM extraction, previously described,with minor modifica- 
tions (Barbi et al, 1996). Three uniform discs, $3 \mathrm{~mm}$ in diameter, were removed from the filter paper, and prepared using special precautions in order to avoid contamination, as described previously.

Human herpes virus 6 DNA detection Presence of HHV-6 DNA was analysed by a nested PCR, with the primers corresponding to the conserved region of HHV-6 in both variants A and B, amplifying a $173 \mathrm{bp}$ segment (Wang et al, 1996). Purified DNA extracted from HHV-6 strain GS (type A) and strain Z29 (type B) was used as positive controls in all PCRs. The sensitivity estimated using known concentrations of positive controls' DNA was 20-30 genomes/PCR reaction for both strains (Wang et al, 1996).

EBV DNA detection Presence of EBV DNA was analysed by a nested PCR, with the primers corresponding to the fragment of EBV EBNA gene 1 amplifying a 208 bp segment (Cinque et al, 1993; Wang et al, 1996).

HLA PCR As a control for the presence of DNA extracted from Guthrie cards and for DNA amplifiability, a PCR with a set of HLADQ primers was performed (Saiki et al, 1986). The HLA PCRnegative samples were not used for further investigation.

\section{Ethical considerations}

Written informed consent was obtained from patients, controls and parents. The local ethics committee of the Karolinska Institutet at Karolinska University Hospital approved the study protocol.

\section{RESULTS AND DISCUSSION}

The Guthrie cards of all 54 patients with ALL, as well as all 47 healthy controls, were tested negative by PCR for both HHV-6 DNA and EBV DNA. All samples contained amplifiable DNA when tested by HLA-DQ PCR. Human herpes virus 6 or EBV DNA could be detected in the blood as well as in the 'spiked' Guthrie cards from the two BMT patients with HHV-6 and EBV infection, respectively.

The use of stored Guthrie cards as a source of DNA has been shown to have several uses. DNA is relatively stable and blood collected from newborns contains 2-3 times higher levels of nucleic acid when compared to adults. In several studies, it has been shown that viral DNA could be successfully amplified from Guthrie cards in case of congenital CMV, HSV and HIV infection (Cassol et al, 1991; Barbi et al, 1996; Fischler et al, 1999).The difficulty in dividing childhood leukaemia into homogenous subgroups presents a problem for investigating different aetiological factors. In our material, the majority of children had pre-BALL. It has been suggested that infection in utero with a virus that has the oncogenic potential could be involved in the initiation of ALL, by inducing genomic instability in B lymphocytes. Twin studies suggest that an additional molecular event or exposure is then required postnatally for the preleukaemic clone to expand. The second event, leading to leukaemia, can occur at a time of maximum stress on lymphocyte precursor proliferation and may be promoted by exposure to a common infectious agent (Greaves, 1999; Wiemels et al, 1999).

Space-time clustering of ALL has raised the possibility of an infectious agent in ALL. Later, Kinlen and others proposed that the mixing of previously separate urban and rural groups of people, as in the creation of new towns in rural construction projects or military camps, may raise the incidence of leukaemia by facilitating transmission of infective agents (Kinlen et al, 1990; Kinlen and Balkwill, 2001; Kinlen et al, 2002). Although most reports have emphasised space-time clustering at diagnosis
(Petridou et al, 1996; Alexander et al, 1997; Gilman et al, 1999), recent studies have detected space-time clustering around the time of birth (Alexander, 1992; Gustafsson and Carstensen, 1999, 2000; Birch et al, 2000). While this may reflect exposures operating in utero, the leukaemogenic infection may occur after birth since addresses used in space-time clustering studies often apply well after birth. Another model for virus transmission during pregnancy is suggested by observations that leukaemia in cats can result from maternal transmission (Knox et al, 1980). Intrauterine infection is a result of either primary maternal infection or reactivation of the latent infection. Primary infection with HHV-6 during pregnancy is a rare event, since more than $90 \%$ are seropositive at the age of 3, infection being most frequent during the first year of life (Dahl et al, 1990, 1999; Hall et al, 1994). Human herpes virus 6 reactivation may be more common than primary infection in pregnancy and foetal transmission may occur in about $1 \%$ of pregnancies (Dahl et al, 1999). Human herpes virus 6 was first isolated from cultures of the peripheral blood lymphocytes of patients with AIDS and lymphoproliferative diseases; it is considered to play an important role in the development of complications after stem cell transplantation (Salahuddin et al, 1986; Matsuda et al, 1999).

Epstein-Barr virus was first discovered through its close relationship with the endemic form of Burkitt lymphoma, the most common childhood cancer in equatorial Africa (Burkitt, 1958; Epstein et al, 1964). Epstein-Barr virus reactivation is also frequent in organ and stem cell transplant patients in whom it can produce lethal lymphoproliferative disease (Gustafsson et al, 2000). The experience of EBV in the transplant setting clearly illustrates the ability of the EBV virus to reactivate the immunosuppressant and its oncological potential. Besides the transplant setting, EBV is also frequently reactivated during pregnancy (Costa et al, 1985). The seroprevalence of EBV in adults has been reported to be higher than 90\% (Rickinson, 1996).In a recent study (Lehtinen et al, 2003), maternal reactivation of EBV infection (as shown by serum EBV IgM antibodies) during the first trimester was associated with a significantly increased risk of developing ALL in the offspring. As the specificity of IgM is known to be imperfect in EBV reactivation, PCR analysis was performed in addition. Of 77 IgM-positive women, there were only two that were EBV DNA positive, compared to three cases of EBV DNA-positive women in the control group, indicating that viraemia was uncommon during reactivaton (Lehtinen et al, 2003).

The fact that neither HHV-6 DNA nor EBV were detected in dried blood spots obtained from newborns at birth indicates that congenital infections with these viruses are uncommon. The possibility of false-negative results due to infection early in pregnancy and being latent at birth must be considered. However, for congenital CMV infection, it has been shown that Guthrie cards were positive for CMV DNA even when the maternal infection took place during the first or second trimester, indicating that viraemia persisted to birth (Peckham, 1991). Similar findings were reported in cases of intrauterine foetal death in association with parvovirus B19 infection (Tolfvenstam et al, 2001).

Human herpes virus 6 DNA and EBV-DNA were detected by PCR in the blood from Guthrie cards neither in children who had developed ALL nor from healthy controls. Hence, it is unlikely that childhood ALL is associated with an in utero infection with these viruses, although a latent infection cannot be excluded by this method, nor infection after birth. In view of the epidemiological evidence for a relation between childhood ALL and infection, the search for a virus aetiology must continue.

\section{ACKNOWLEDGEMENTS}

We would like to thank Britta Lindqvist and Marie Sandberg for their excellent work, in organising the neonatal spots; 
Claes Gutenberg, Associate Professor, head of the PKU-Laboratory, for providing us with Guthrie cards; and Helena Dahl for providing us with sera from a patient that developed a HHV-6 infection. This study was supported by grants from the Mary Béves
Foundation, the Tobias Foundation, the Swedish Child Cancer Foundation, the Swedish Cancer Foundation, the Stockholm Cancer Society, and the Stockholm City Council and the Karolinska Institutet.

\section{REFERENCES}

Alexander FE (1992) Space-time clustering of childhood acute lymphoblastic leukaemia: indirect evidence for a transmissible agent. Br J Cancer 65: $589-592$

Alexander FE, Chan LC, Lam TH, Yuen P, Leung NK, Ha SY, Yuen HL, Li CK, Lau YL, Greaves MF (1997) Clustering of childhood leukaemia in Hong Kong: association with the childhood peak and common acute lymphoblastic leukaemia and with population mixing. $\mathrm{Br} J$ Cancer 75: $457-463$

Barbi M, Binda S, Primache V, Novelli C (1996) Cytomegalovirus in peripheral blood leukocytes of infants with congenital or postnatal infection. Pediatr Infect Dis J 15: 898-903

Birch JM, Alexander FE, Blair V, Eden OB, Taylor GM, McNally RJ (2000) Space-time clustering patterns in childhood leukaemia support a role for infection. Br J Cancer 82: $1571-1576$

Burkitt D (1958) A sarcoma involving the jaws in African children. Br J Surg 46: $218-223$

Cassol S, Salas T, Arella M, Neumann P, Schechter MT, O'Shaughnessy M (1991) Use of dried blood spot specimens in the detection of human immunodeficiency virus type 1 by the polymerase chain reaction. J Clin Microbiol 29: $667-671$

Cinque P, Brytting M, Vago L, Castagna A, Parravicini C, Zanchetta N, D’Arminio Monforte A, Wahren B, Lazzarin A, Linde A (1993) EpsteinBarr virus DNA in cerebrospinal fluid from patients with AIDS-related primary lymphoma of the central nervous system. Lancet 342: 398-401

Cnattingius S, Ericson A, Gunnarskog J, Kallen B (1990) A quality study of a medical birth registry. Scand J Soc Med 18: 143-148

Costa S, Barrasso R, Terzano P, Zerbini M, Carpi C, Musiani M (1985) Detection of active Epstein-Barr infection in pregnant women. Eur J Clin Microbiol 4: 335-336

Dahl H, Fjaertoft G, Norsted T, Wang FZ, Mousavi-Jazi M, Linde A (1999) Reactivation of human herpesvirus 6 during pregnancy. J Infect Dis 180: $2035-2038$

Dahl H, Linde A, Sundqvist VA, Wahren B (1990) An enzyme-linked immunosorbent assay for IgG antibodies to human herpes virus 6.J Virol Methods 29: 313 - 323

Doll R (1989) The epidemiology of childhood leukemia. J R Stat Soc Series 152: $341-351$

Epstein MA, Achong BG, Barr YM (1964) Virus particles in cultured lymphoblasts from Burkitt's lymphoma. Lancet 15: $702-703$

Fischler B, Rodensjo P, Nemeth A, Forsgren M, Lewensohn-Fuchs I (1999) Cytomegalovirus DNA detection on Guthrie cards in patients with neonatal cholestasis. Arch Dis Child Fetal Neonatal Ed 80: F130-F134

Gale KB, Ford AM, Repp R, Borkhardt A, Keller C, Eden OB, Greaves MF (1997) Backtracking leukemia to birth: identification of clonotypic gene fusion sequences in neonatal blood spots. Proc Natl Acad Sci USA 94: 13950 - 13954

Gilman EA, McNally RJ, Cartwright RA (1999) Space-time clustering of acute lymphoblastic leukaemia in parts of the U.K. (1984-1993). Eur J Cancer 35: 91 - 96

Greaves M (1999) Molecular genetics, natural history and the demise of childhood leukaemia. Eur J Cancer 35: 1941 - 1953

Gustafsson A, Levitsky V, Zou JZ, Frisan T, Dalianis T, Ljungman P, Ringden O, Winiarski J, Ernberg I, Masucci MG (2000) Epstein-Barr virus (EBV) load in bone marrow transplant recipients at risk to develop posttransplant lymphoproliferative disease: prophylactic infusion of EBV-specific cytotoxic T cells. Blood 95: 807-814

Gustafsson B, Carstensen J (1999) Evidence of space-time clustering of childhood acute lymphoblastic leukaemia in Sweden. Br J Cancer 79: $655-657$

Gustafsson B, Carstensen J (2000) Space-time clustering of childhood lymphatic leukaemias and non-Hodgkin's lymphomas in Sweden. Eur J Epidemiol 16: 1111 - 1116

Hall CB, Long CE, Schnabel KC, Caserta MT, McIntyre KM, Costanzo MA, Knott A, Dewhurst S, Insel RA, Epstein LG (1994) Human herpesvirus-6 infection in children. A prospective study of complications and reactivation. $N$ Engl J Med 331: $432-438$

Isa A, Priftakis P, Broliden K, Gustafsson B (2004) Human parvovirus B19 DNA is not detected in Guthrie cards from children who have developed acute lymphoblastic leukemia. Pediatr Blood Cancer 42: $357-360$

Kinlen L, Jiang J, Hemminki K (2002) A case-control study of childhood leukaemia and paternal occupational contact level in rural Sweden. $\mathrm{Br} J$ Cancer 86: $732-737$

Kinlen LJ, Balkwill A (2001) Infective cause of childhood leukaemia and wartime population mixing in Orkney and Shetland. Lancet 358: 155

Kinlen LJ, Clarke K, Hudson C (1990) Evidence from population mixing in British New Towns 1946-85 of an infective basis for childhood leukaemia. Lancet 336: $577-582$

Knox EG, Stewart A, Kneale G (1980) Childhood leukaemia and motherfoetus infection. Br J Cancer 42: $158-161$

Lehtinen M, Koskela P, Ogmundsdottir HM, Bloigu A, Dillner J, Gudnadottir M, Hakulinen T, Kjartansdottir A, Kvarnung M, Pukkala E, Tulinius H, Lehtinen T (2003) Maternal herpesvirus infections and risk of acute lymphoblastic leukemia in the offspring. Am J Epidemiol 158: $207-213$

Matsuda Y, Hara J, Miyoshi H, Osugi Y, Fujisaki H, Takai K, Ohta H, Tanaka-Taya K, Yamanishi K, Okada S (1999) Thrombotic microangiopathy associated with reactivation of human herpesvirus-6 following high-dose chemotherapy with autologous bone marrow transplantation in young children. Bone Marrow Transplant 24: 919-923

Ohls R, Christensen R (2000) The Development of the hematopioetic system. In Nelson Textbook of Pediatrics, Behrman R, Jenson H (eds) pp 1456, Philadelphia: Saunders Company

Peckham CS (1991) Cytomegalovirus infection: congenital and neonatal disease. Scand J Infect Dis Suppl 80: 82-87

Petridou E, Revinthi K, Alexander FE, Haidas S, Koliouskas D, Kosmidis H, Piperopoulou F, Tzortzatou F, Trichopoulos D (1996) Space-time clustering of childhood leukaemia in Greece: evidence supporting a viral aetiology. Br J Cancer 73: 1278-1283

Priftakis P, Dalianis T, Carstensen J, Samuelsson U, Lewensohn-Fuchs I, Bogdanovic G, Winiarski J, Gustafsson B (2003) Human polyomavirus DNA is not detected in Guthrie cards (dried blood spots) from children who developed acute lymphoblastic leukemia. Med Pediatr Oncol 40: $219-223$

Rickinson ABKE (1996) Epstein - Barr virus. Virology, In Fields BNK (ed)

Ross JA (1999) Epidemiologic studies of childhood leukemia: where do we go from here? Med Pediatr Oncol 32: 65-67

Saiki RK, Bugawan TL, Horn GT, Mullis KB, Erlich HA (1986) Analysis of enzymatically amplified beta-globin and HLA-DQ alpha DNA with allelespecific oligonucleotide probes. Nature 324: 163-166

Salahuddin SZ, Ablashi DV, Markham PD, Josephs SF, Sturzenegger S, Kaplan M, Halligan G, Biberfeld P, Wong-Staal F, Kramarsky B et al. (1986) Isolation of a new virus, HBLV, in patients with lymphoproliferative disorders. Science 234: 596-601

Salonen MJ, Siimes MA, Salonen EM, Vaheri A, Koskiniemi M (2002) Antibody status to HHV-6 in children with leukaemia. Leukemia 16: $716-719$

Smith M (1997) Considerations on a possible viral etiology for B-precursor acute lymphoblastic leukemia of childhood. J Immunother 20: 89-100

Tolfvenstam T, Papadogiannakis N, Norbeck O, Petersson K, Broliden K (2001) Frequency of human parvovirus B19 infection in intrauterine fetal death. Lancet 357: 1494-1497

Wang FZ, Dahl H, Linde A, Brytting M, Ehrnst A, Ljungman P (1996) Lymphotropic herpesviruses in allogeneic bone marrow transplantation. Blood 88: $3615-3620$

Wiemels JL, Cazzaniga G, Daniotti M, Eden OB, Addison GM, Masera G, Saha V, Biondi A, Greaves MF (1999) Prenatal origin of acute lymphoblastic leukaemia in children. Lancet 354: 1499-1503 